\title{
Association between Social Skills, Sociodemographic Factors and Self-Statements during Public Speaking by University Students
}

\author{
Murilo Freitas Bauth*, 1 \\ Orcid.org/0000-0003-4003-9498 \\ Antonio Paulo Angélico ${ }^{1}$ \\ Orcid.org/0000-0002-6926-0439 \\ Daniela Carine Ramires de Oliveira ${ }^{1}$ \\ Orcid.org/0000-0002-9573-8424
}

${ }^{1}$ Universidade Federal de São João del-Rei, São João del-Rei, MG, Brasil

\begin{abstract}
Possessing a good repertoire of interpersonal skills and a good performance when speaking in public can be considered indispensable for the social and academic adaptation of college students. The aim was to characterize and compare the social skills repertoire of college students from different fields of study (the human, exact and biological sciences) and from different higher education institutions (public and private), and to investigate the associations between these abilities and their self-assessment about speaking in public. A total of 818 college students took part, who answered the Social Skills Inventory (IHS-Del-Prette), Self-Statements During Public Speaking Scale and a Socio-demographic and Occupational Questionnaire. The groups did not differ significantly in relation to their social skills' repertoire, with most of the participants $(n=432)$ having a below-average repertoire of abilities when compared to the normative group of the instrument. It was found that male college students and those who had a partner, a job or their own income, and direct contact with the public gave more positive self-assessments about speaking in public. The skills' classes of self-exposure to strangers and new situations, self-confidence in expressing positive feelings, conversation and social resourcefulness, selfcontrol of aggressivity, and coping and self-confidence with risk, and having a vocational course were the variables that predicted a more positive self-assessment by college students about speaking in public. Keywords: Social skills, public speaking, performance assessment, social interaction, college students.

\section{Associação entre Habilidades Sociais, Fatores Sociodemográficos e Autoavaliações ao Falar em Público de Estudantes Universitários}

\section{Resumo}

Possuir um bom repertório de habilidades interpessoais e de desempenho ao falar em público pode ser considerado indispensável para a adaptação social e acadêmica dos universitários. Objetivou-se

* Mailing address: Rua José Haddad 30, Cascalho, Lavras - MG, Brazil 37200-000. Phone: (35) 3826-2034 / (35) 98414-6414. E-mail: murilobauth.psi@gmail.com.br 
caracterizar e comparar o repertório de habilidades sociais de universitários provindos de diferentes áreas do conhecimento (humanas, exatas e biológicas) e instituições de ensino superior (pública e privada), bem como investigar as associações entre estas habilidades e as autoavaliações ao falar em público. Participaram 818 universitários, que responderam ao Inventário de Habilidades Sociais (IHSDel-Prette), Escala de Auto-Avaliação ao Falar em Público e um Questionário Sociodemográfico e Ocupacional. Os grupos não diferiram significativamente quanto ao repertório de habilidades sociais, com a maioria dos participantes $(n=432)$ apresentando um repertório de habilidades abaixo da média em relação ao grupo normativo do instrumento. Verificou-se que os universitários do gênero masculino e aqueles que possuíam um companheiro, trabalho ou renda própria e contato direto com o público apresentavam autoavaliações ao falar em público mais positivas. As classes de habilidades de autoexposição a desconhecidos, autoafirmação na expressão de sentimento positivo, conversação e desenvoltura social, autocontrole da agressividade e enfrentamento e autoafirmação com risco e possuir um curso profissionalizante foram as variáveis preditoras de uma autoavaliação mais positiva dos universitários ao falar em público.

Palavras-chave: Habilidades sociais, falar em público, avaliação do desempenho, interação social, universitários.

\section{Asociación entre Habilidades Sociales, Factores Sociodemográficos y Autoevaluaciones al Hablar en Público de Estudiantes Universitarios}

\section{Resumen}

Poseer un buen repertorio de habilidades interpersonales y de desempeño al hablar en público puede ser considerado indispensable para la adaptación social y académica de los universitarios. Se objetivó caracterizar y comparar el repertorio de habilidades sociales de universitarios provenientes de diferentes áreas del conocimiento (humanas, exactas y biológicas) e instituciones de enseñanza superior (pública y privada), así como investigar las asociaciones entre estas habilidades y las autoevaluaciones al hablar en publico. Participaron 818 universitarios, que respondieron al Inventario de Habilidades Sociales (IHS-Del-Prette), Self Statements During Public Speaking Scale y un Cuestionario Sociodemográfico y Ocupacional. Los grupos no diferían significativamente en cuanto al repertorio de habilidades sociales, con la mayoría de los participantes $(n=432)$ presentando un repertorio de habilidades por debajo de la media en relación al grupo normativo del instrumento. Se comprobó que los universitarios masculinos y aquellos que tenían un compañero, trabajo, ingresos propios y contacto directo con el público, presentaban autoevaluaciones más positivas al momento de hablar en público. Los tipos de habilidades de autoexposicion a desconocidos, el reconocimiento en la expresión del sentimiento positivo, el diálogo y el desenvolvimiento social, el autocontrol de la agresividad y haber hecho un curso profesional, fueron las variables clave al momento de una auto evaluación positiva de los universitarios al hablar en público.

Palabras clave: Habilidades sociales, hablar en público, evaluación del rendimiento, interacción social, universitarios.

In the first years of undergraduate courses, students are reported to find it difficult to adapt because college is a transition phase in the life of individuals, during which they are required to adjust to the changes they are experiencing in this period (Furtado, Falcone, \& Clark, 2003), such as developing greater autonomy with regard to enhancing the knowledge learned in the classroom by reading complex scientific texts, undertaking practical activities and professional internships, and acquiring greater maturity in order to relate to colleagues, teachers 
and employees (Soares \& Del Prette, 2015). In the 2011 to 2014 period there was a $16 \%$ increase in the number of students enrolled in higher education. The number of courses that were put on hold [the student dropped out of the course, but with the intention of returning at a future date], however, increased by $60 \%$, while the number of those graduating with a degree increased by only a further $1 \%$ (Saldaña, 2016).

According to Lobo (2017), the annual dropout rate in 2011 and 2015 for all higher education institutions (HEIs) in Brazil was $22 \%$, with the public sector having a lower rate $(15 \%)$ and the private sector a higher rate $(24 \%)$. According to this author, the waste of resources resulting from dropout in both public and private HEIs exceeds R $\$ 10$ billion.

College dropout is understood to be a complex phenomenon that has been increasing over the years (Cordasso, Silva, Pelegrini, \& Baggenstoss, 2016) and is one of the biggest problems for both public and private HEIs. Among the aspects that lead to college students choosing to drop out of higher education are problems with personal relationships, which can increase dissatisfaction with the college experience and favor dropout (Bardagi \& Hutz, 2012; Castro \& Teixeira, 2013; PascuaCantarero, 2016).

The field of social skills forms part of the dynamics between interpersonal relationships and academic adaptation to higher education (Soares \& Del Prette, 2015). Social skills are defined as the different classes of behavior that exist in an individual's repertoire for adequately dealing with the demands of interpersonal situations (Del Prette \& Del Prette, 2001a). According to Angélico, Crippa, and Loureiro (2013), the social functioning and adaptive capacity of individuals who are deficient in these skills may be impaired. The types of deficit an individual may have are classified as: (a) acquisition deficit, characterized by the absence of specific skills in an individual's repertoire that they have not learned because of a lack of appropriate educational opportunities or contingencies (Del Prette \& Del Prette 2005); (b) performance deficit, defined as being the failure to perform a particular skill at an acceptable level given the demands of the environment; and (c) fluency deficit, which occurs when the individual does not reach the expected levels of proficiency in their performance (Angélico et al., 2013).

The relationship between social skills and the student's academic adaptation has been investigated in various studies. A recent study by Soares, Santos, Andrade, and Souza (2017) investigated the relationships that exist between social skills, academic expectations and adaptation to college in personal, interpersonal, vocational and institutional terms, and aspects referring to study skills (time management, for example), using a sample of 177 male and female college students, aged 17- 44, from public and private institutions in the State of Rio de Janeiro. The results indicated that college students who had a better-prepared repertoire of social skills and realistic expectations about achieving their academic and professional goals within the college context adapted better to higher education.

In addition to a repertoire of general social skills, a good repertoire of public speaking skills is considered essential for the academic and social performance of college students (Angélico, 2009), because during their time at college students come into contact with various public speaking demands, such as having to present their work, classroom seminars and expressing their opinions in a group situation (Landim et al., 2000). But individuals who are deficient in these skills, who are afraid of possible adverse consequences (Clevenger \& Phifer, 1959), and who are lacking in preparation, familiarity with these tasks (Clevenger \& Phifer, 1959; Goberman, Hughes, \& Haydock, 2011) or negative cognition (Weeks \& Zoccola, 2015), may experience high levels of anxiety during activities that require the use of such skills (Lima \& Soares, 2015).

Social interaction is the basis of many professional activities. Social interaction may be a fundamental characteristic of the performance of professionals linked to the humanities, for example. On the other hand, social interaction may not be an essential aspect for a successful 
professional performance by those working in the exact sciences. Regardless of the area of professional activity, however, at some time and to a greater or lesser extent, there needs to be some social interaction (Del Prette, Del Prette, \& Correia, 1992) and therefore a good repertoire of social skills can be extremely important both for the individual's adaptation to higher education and subsequently for their entry into, and continuity in the labor market (Carter, Austin, \& Trainor, 2012; Phillips, Kaseroff, Fleming, \& Huck, 2014).

To identify the research that has been published on social skills and self-assessments (cognition) in relation to the situation of college students speaking in public, a systematic search was carried out in the literature, using the indexers of the SciELO, LILACS, PUBMED, IndexPsi, MEDLINE, PsycINFO, Science Direct and ISI Web of Knowledge scientific journals, and a combination of the following descriptors: social skills, public speaking, fear of public speaking, public speaking anxiety, undergraduates, and college students. The inclusion criteria used to guide the search procedure in the indexers were that: the main objective of the studies was to characterize and compare the repertoire of social skills and/or self-assessments about speaking in public; its sample should consist exclusively of college students; and they were published in the period between 2000 and 2017. Qualitative research, instrument validation and intervention, research that assessed clinical populations or only college students enrolled on isolated undergraduate courses and not courses grouped in academic areas (human, exact and biological sciences) were excluded.

Using the above inclusion and exclusion criteria, only two Brazilian studies were identified that characterized and compared the repertoire of social skills of college students from the humanities and exact sciences, and one that investigated self-assessments about speaking in public in college students (Marinho, Medeiros, Gama, \& Teixeira, 2017). Bandeira, Quaglia, Bachetti, Ferreira, and Souza (2005) investigated the assertive behavior of college students $(N=$ 135 ) of both genders, with ages ranging between
21 and 44 years old, who were enrolled on courses in the humanities $(n=60)$ and exact sciences ( $n$ $=75$ ) of a college in the interior of the State of Minas Gerais. The instrument used to measure the level of student assertiveness was the Rathus Assertiveness Scale. The results showed that college students enrolled in exact science courses were significantly more assertive than those on humanities courses $(t=2.23 ; p=.03)$.

Bolsoni-Silva and Loureiro (2015) characterized and compared the social skills' repertoire of 461 college students of both genders, without any type of mental disorder, who were enrolled on courses in the humanities $(n=199)$ and exact science $(n=260)$ in a college in the State of São Paulo. A structured clinical interview for DSM-IV (SCID-I - clinical version) was initially conducted with the students in order to select only those who did not meet the diagnostic criteria for mental disorder. After the interview, their social skills were assessed by way of the Skills, Behaviors and Contexts Questionnaire for College Students (QHC). It was observed that, generally speaking, students who had a developed repertoire of social skills were those who were enrolled on courses in the humanities area, were female $(n=201)$, were in employment $(n=180)$, and lived with other students $(n=199)$.

Marinho et al. (2017) evaluated the prevalence of fear of public speaking in 1,135 college students from a public university in Belo Horizonte (Minas Gerais). It was found that $63.9 \%$ of the sample reported being afraid of speaking in public, this fear being more prevalent in women $(72.5 \%)$ who, in turn, presented more negative self-assessments with regard to this situation than men $(p=.006)$.

From the studies cited, it was found that the samples comprised only college students enrolled in human science and exact science courses in public higher education institutions and one of them only evaluated the assertiveness of these students (Bandeira et al., 2005) and considered one class of social skills. Furthermore, no study was identified that investigated the relationship between social skills and self-assessments (cognition) with regard to public speaking. 
Based on the literature consulted, the research problem identified was the lack of studies aimed at characterizing and comparing the repertoire of social skills of college students from different areas of knowledge (the exact, human and biological sciences) and higher education institutions (private and public), and investigating the relationship of these skills with self-assessments about speaking in public. This particular research, therefore, aimed to: (a) check if there are differences in the social skills' levels of college students in different areas of knowledge and from HEIs; (b) evaluate the relationship between social skills and self-assessments about speaking in public; and (c) investigate the sociodemographic, occupational, and interpersonal factors (relating to the repertoire of social skills) that are the predictors of college students' levels of self-assessment about public speaking.

Considering the data presented, it was postulated that students in the human sciences would have a better-prepared repertoire of social skills than students from the exact and biological sciences. This hypothesis is generally supported because social interaction may be a fundamental characteristic of the activities of human science courses when compared with other areas of knowledge (Del Prette et al., 1992). It was also hoped to check the predictive power of a betterprepared repertoire of social skills for selfassessments about a public speaking situation.

\section{Method}

\section{Participants}

A total of 818 male and female college students aged between 17 and 57 years old $(M=$ $23.04, S D=5.50)$ on human $(n=318)$, exact $(n$ $=302)$ and biological $(n=198)$ science courses from two highereducation institutions (one public and one private) in the State of Minas Gerais took part. Male and female students aged 17 years and older, who were regularly enrolled up to the fifth educational module on undergraduate courses in different academic areas (human, exact and biological sciences) were included. The exclusion criteria were college students not agreeing to take part in the survey, not being present on the day the data were collected, or not completing, or completing in duplicate, items on the measurement instruments.

The non-probabilistic sampling technique, known as purposive sampling, was used. The basic hypothesis of this technique is that with good judgment and using an appropriate strategy, cases can be carefully selected that should be included in the sample, and so samples can be developed that are satisfactory to the needs of the research (Selltiz, Wrightsman, \& Cook, 1987). The researchers considered it appropriate to select a sample that comprised students enrolled in the fifth educational module of undergraduate courses, since it was believed that: (a) these students have already completed half of their university education and, therefore, are established in the course for which they are enrolled; and (b) they have not yet been exposed to obligatory syllabus internships, which can develop or improve their social skills and so interfere with the interpretation of the results.

On some occasions during data collection it was necessary to select students from initial modules because, for some undergraduate courses the fifth module, or previous modules, already included internship experience in their syllabus. A strategy was adopted, therefore, of selecting the prior module closest to the fifth module, before the students had had any contact with these internships. In those cases in which the class included students from other modules (for example, a fifth module class that had students from more advanced modules, who had enrolled in the discipline again because they had previously failed), the researcher asked if they had had any experience of compulsory syllabus internships, and if so, they were dispensed with and thus unable to participate in the study.

The following undergraduate courses at the public institution made up the research sample: biological sciences, philosophy, physics, history, literature, medicine, teaching, psychology, chemistry, economics, production engineering, electrical engineering, mechanical engineering, mathematics, architecture and town planning, applied arts, computer science, accounting, social communication (journalism), physical 
education, geography, music, theater and animal husbandry. In the private institution the courses were: administration, architecture and town planning, law, nursing, civil engineering, production engineering, physiotherapy, veterinary medicine, dentistry and psychology.

\section{Instruments}

The following instruments were used in the present study: Social Skills Inventory (IHS-DelPrette), Self-Statements During Public Speaking Scale (SSPS) and a Sociodemographic and Occupational Questionnaire. These instruments are described below.

Social Skills Inventory (IHS-Del-Prette): a self-report instrument, comprising 38 items, which correspond to an action or the feelings of the individual in a given social situation. The respondent must indicate the frequency with which they act or feel in relation to each interpersonal situation that is presented. They do so by means of a Likert scale, which varies from never or rarely to always or almost always (Del Prette \& Del Prette, 2001b).

An analysis of the psychometric properties found in the original study with college students gave the following results: positive indices of item discrimination, ranging from 3.0 to 16.7; positive indices of the total item-score correlation, with only two being non-significant and ten being below 0.30 ; satisfactory internal consistency, with a Cronbach's alpha of 0.75; and factor structure with five main factors, evaluated using the Alpha method with Varimax rotation, the alpha coefficients of which ranged from 0.74 to 0.96 , thus explaining $92.75 \%$ of the total variance. The factors were labelled: Coping and self-confidence with risk (Factor 1); Self-confidence in expressing positive feelings (Factor 2); Conversation and social resourcefulness (Factor 3); Self-exposure to strangers and new situations (Factor 4); and Self-control of aggressivity (Factor 5; Del Prette, Del Prette, \& Barreto, 1998). Reliability was assessed using the test and retest method, when a correlation coefficient of $0.90(p=.001)$ was obtained (Bandeira, Costa, Del Prette, Del Prette, \& Gerk-Carneiro, 2000).
Self-Statements during Public Speaking Scale (SSPS): this is a self-administered instrument that aims to assess self-perception of performance in the specific situation of speaking in public. It was developed by Hofmann and DiBartolo (2000), and was adapted for the Brazilian context by Osório, Crippa, and Loureiro (2008), and is now being called the Escala de Auto-Avaliação ao Falar em Público [Self-Assessment when Speaking in Public Scale]. Its instructions require the respondent to imagine the things they usually think about with regard to themselves when they find themselves in a situation in which they have to speak in public. They are asked to consider how much they agree with the situations and to note down their answers on a Likert scale, ranging from 0 (totally disagree) to 5 (fully agree).

The psychometric qualities of the instrument are adequate in terms of their reliability and validity. The correlation of the items with the total score varied between 0.44 and 0.71 . The internal consistency gave a Cronbach's alpha of 0.90 for the total scale, 0.80 for the positive self-assessment subscale (Factor 1) and 0.78 for the negative self-assessment subscale (Factor 2 ). For the latter subscale, the item score is inverted, in other words, the lower the mean of the score, the greater the negative assessment the individual has of himself/herself (Osório et al., 2008). The validity of the construct was studied by way of factor structure analysis, using the Principal Component Analysis technique with Varimax rotation. The two above-mentioned factors, which together corresponded to $52 \%$ of the data variance, were extracted. Discriminative validity was analyzed using Student's $t$-test, the objective being to check the ability of SSPS to discriminate subjects as a function of gender. According to the results, only the negative subscale was discriminatory $(t=-4.802, p<.001)$, showing that women had a lower mean score, in other words, a greater negative assessment of themselves (Osório, Crippa, \& Loureiro, 2012).

Socio-demographic and Occupational Questionnaire: its aim is to assess the sociodemographic and occupational characteristics of the college students. The following aspects were 
assessed: gender, age, schooling, marital status, housing status, higher education institution, undergraduate course in which they were enrolled, whether they had completed another undergraduate course or vocational course, whether they worked or had their own income, their profession, whether they had direct contact with other people, or served the public, the type of school in which they had finished high school (private or public), and if they had any kind of disability and had used psychotropic medication.

\section{Data Collection Procedure}

The measurement instruments were applied by the researcher in a collective manner, in the classroom, with the authorization of the course coordinator and the teacher responsible for the discipline being taught at the time the data were collected. The researcher explained the objectives and procedures of the study to the students and invited them to participate. Those who agreed to take part were asked to read the Term of Free and Informed Consent (TCLE) and then to sign it. Students who did not agree to take part in the activity for any reason were dispensed with.

The students then received a notebook containing the instruments in the following order: Socio-demographic and Occupational Questionnaire, Social Skills Inventory (IHSDel-Prette) and the Self-Statements during Public Speaking (SSPS) scale. The whole data collection procedure lasted approximately one hour.

\section{Data Analysis Procedure}

The classification of the social skills repertoire of the college students was assessed according to the instructions set out in the IHS-Del-Prette application, calculation and interpretation manual. Their factor scores were generated by way of the $\mathrm{T}$ results and not by their simplified correction (Del Prette \& Del Prette, 2001b). Repertoire classification is divided into five categories of percentiles, namely: An elaborate repertoire of social skills $(P \geq 75)$; A good, above the median repertoire of social skills $(P>50$ and $<75)$; A median repertoire of social skills $(P=50)$; A good, below the median repertoire of social skills $(P=25$ and $<50)$; and Indicated for Social Skills' Training (deficient repertoire, with $P<25$ ).

The collected data were analyzed using the Statistical Package for Social Sciences (SPSS), version 20.0 for Windows. The statistical tests were carried out using a $p<.05$ significance level. Descriptive statistical analyses were carried out by calculating the means, standard deviations and percentages in order to describe the sociodemographic and occupational characteristics of the sample and to analyze the IHS-Del-Prette and SSPS instrument scores. The sample size of this research was 818 participants. According to the central limit theorem (Bussab \& Morettin, 2017), therefore, the sampling distribution of the mean of the observations is close to a normal and, consequently, parametric inference was used for all the analyses carried out in this study.

In order to check the equivalence of the groups according to the academic areas (humanities, exact and biological sciences) and types of HEI (public and private) with regard to their socio-demographic and occupational variables, we used one-factor variance analysis (ANOVA) with a post hoc Bonferroni test for continuous variables and the chi-square test for categorical variables. A one-factor ANOVA with a post hoc Bonferroni test was also used to examine the existence of significant differences between the groups of students according to their academic areas and types of HEI in relation to the total scores and IHS-Del-Prette factors. The chi-square test was also used to compare the same groups of college students as to the classifications of their social skills repertoire, according to the instructions contained in the IHS application, calculation and interpretation manual (Del Prette \& Del Prette, 2001b).

The data relating to the total scores of the IHS-Del-Prette and SSPS, and the overall score of the social public speaking skills (HSFP) extracted from the HIS, were correlated using the Pearson Linear Correlation test. For analyzing the general HSFP score, those IHS items that best fit the public speaking skill were selected and added together, namely: items 9 ("I avoid 
making presentations or giving talks to unknown people"), 11 ("If the teacher or a leader says something that's incorrect in the classroom or in a meeting, I express my point of view"), 14 ("I say something [e.g. in talks] in the classroom or at work, when I'm invited to do so"), 16 ("When I'm in a group of people I know, if I do not agree with the majority, I express my disagreement verbally") and 29 ("When I don't understand an explanation of something that I'm interested in at school or in work, I ask the questions I consider necessary to clarify the point for me"). These items had in common the component of speaking and/or exposing themselves in public, some of them with the possibility of being rejected, contested or opposed by those listening (Angélico, Crippa, \& Loureiro, 2012).

A multiple linear regression analysis using the Stepwise method was carried out to investigate the predictive power of the sociodemographic and occupational characteristics and the general social skills in relation to the self-assessments of college students with regard to speaking in public. Student's $t$-test, one-factor ANOVA with a post hoc Bonferroni test, and Pearson's Linear Correlation test were used to select the socio-demographic, occupational and interpersonal variables (relative to the social skills repertoire) that would be employed in this analysis. Therefore, those variables that were identified as being significant $(p<.05)$ were used, as were those with a value of $p \leq .25$, in line with the recommendations of Hosmer and Lemeshow (2000). These authors recommend that variables with a value of $p \leq .25$ be used, because they may become significant in the regression analysis.

\section{Ethical Procedures}

This research was authorized by both higher education institutions and duly approved by the Research with Humans Ethics Committee (CEPES) and the Research Ethics Committee (CEP) of the universities (CAAE No. 64713817.0.1001.5545 and No. 64713817.0.3001.5116, respectively). Data were collected in accordance with ethical standards, as per Resolution 466/2012 of the Brazilian
Health Council. The college students took part voluntarily and data were only collected after they and the coordinators of the undergraduate courses of both institutions had signed the Term of Free and Informed Consent (TCLE).

\section{Results}

With regard to equivalence among college students, it was found that there were significant differences in distributions for most of the sociodemographic and occupational variables that were being investigated $(p<.05)$, except for housing status, has some type of disability and psychotropic medication. As for the classification of the social skills repertoire of the whole sample, the majority of the college students ( $n$ $=284 ; 34.7 \%$ ) were assessed as being deficient, while $18.1 \%(n=148)$ were assessed as having a good, but below-the-median repertoire. Most of the sample ( $n=432 ; 52.8 \%)$, therefore, had a below-average repertoire of social skills relative to the instrument's normative group. The other participants had either an elaborate repertoire $(26.9 \%)$, an above-the-median repertoire $(17.6 \%)$, or a median repertoire $(2.7 \%)$.

An ANOVA with post-hoc Bonferroni test was used to compare the IHS-Del-Prette total scores and factors of college students from different areas of knowledge and types of higher education institution. No statistically significant differences were found, however, between the groups in this analysis $(p>.05)$.

The data relating to the comparison of the groups of college students, according to the area of knowledge and types of HEI and as a function of the classifications of their social skills repertoire, are shown in Table 1. The chisquare test was used to evaluate the difference in this distribution between the groups.

No significant differences were found between the groups of students from different areas and types of HEI with regard to the classification of their social skills repertoire ( $p$ $=.437$ ). However, with the exception of students enrolled in exact science courses in the private institution, there was a higher percentage (above $50 \%$ ) of individuals with a good, but below-the- 
Table 1

Classification of the Repertoire of Social Skills of the Sample Participants According to their Areas of Knowledge and Institution Type $(N=818)$

\begin{tabular}{|c|c|c|c|c|c|c|c|}
\hline \multirow{3}{*}{$\begin{array}{l}\text { Classification of the } \\
\text { repertoire of } H S\end{array}$} & \multicolumn{3}{|c|}{ Private } & \multicolumn{3}{|c|}{ Public } & \multirow{3}{*}{ Test of $\chi^{2}$} \\
\hline & Human & Exact & Biological & Human & Exact & Biological & \\
\hline & $n(\%)$ & $n(\%)$ & $n(\%)$ & $n(\%)$ & $n(\%)$ & $n(\%)$ & \\
\hline $\begin{array}{l}\text { An elaborate } \\
\text { repertoire }(P \geq 75)\end{array}$ & $31(27.2 \%)$ & $31(33.0 \%)$ & $34(25.8 \%)$ & $46(22.5 \%)$ & $57(27.4 \%)$ & $21(31.8 \%)$ & \\
\hline $\begin{array}{l}\text { A good, above the } \\
\text { median repertoire } \\
(P>50 \text { and }<75)\end{array}$ & $18(15.8 \%)$ & $16(17.0 \%)$ & $24(18.2 \%)$ & $45(22.1 \%)$ & $32(15.4 \%)$ & $9(13.6 \%)$ & \\
\hline $\begin{array}{l}\text { A median repertoire } \\
(P=50)\end{array}$ & $3(2.6 \%)$ & $3(3.2 \%)$ & $3(2.3 \%)$ & $6(2.9 \%)$ & $6(2.9 \%)$ & $1(1.5 \%)$ & \\
\hline $\begin{array}{l}\text { A good, below the } \\
\text { median repertoire } \\
(P=25 \text { and }<50)\end{array}$ & $23(20.2 \%)$ & $16(17.0 \%)$ & $35(26.5 \%)$ & $34(16.7 \%)$ & $29(13.9 \%)$ & $11(16.7 \%)$ & $\begin{aligned} \chi 2 & =20.34 \\
p & =.437\end{aligned}$ \\
\hline $\begin{array}{l}\text { A deficient repertoire } \\
\text { (indication for THS; } \\
P<25 \text { ) }\end{array}$ & $39(34.2 \%)$ & $28(29.8 \%)$ & $36(27.3 \%)$ & $73(35.8 \%)$ & $84(40.4 \%)$ & $24(36.4 \%)$ & \\
\hline $\begin{array}{l}\text { Total number } \\
\text { of participants }\end{array}$ & 114 & 94 & 132 & 204 & 208 & 66 & \\
\hline
\end{tabular}

Note. $H S=$ social skills; $n=$ number of participants; $\%=$ percentage; $P=$ percentile; $\chi^{2}=$ Chi-squared; $p=$ associated probability.

median and a deficient repertoire classification at all other levels of analysis in the rest of the sample. Pearson's Linear Correlation test was used to investigate the relationships between general social skills, the specific social skills of public speaking and self-assessments about speaking in public. With the exception of the relationship between IHS-Del-Prette's Factor 5 and the SSPS positive subscale, the total score and all the other IHS factors correlated positively and significantly with the total SSPS score and the subscales $(p<.05)$. In this case, the correlation coefficients ranged from 0.10 to 0.60 , in other words, with a magnitude ranging from very low to moderate. The general HSFP score also correlated positively and significantly with the total SSPS score and subscales $(p<.01)$. In this situation, the correlation coefficients ranged from 0.44 to 0.55 , in other words, they were moderate in magnitude.

Table 2 shows the data relative to the statistical analyses of the socio-demographic and occupational factors related to the total SSPS score. Student's $t$-test, one-factor ANOVA with post hoc Bonferroni, and Pearson's Linear Correlation test were used for these analyses.

With regard to the total SSPS score, there were statistically significant differences for the category variables gender, marital status, works or has own income and direct contact with the public, or other people at work. These results indicated that male college students, those with a partner, work or income of their own and direct contact with the public or other people at work provided a more positive self-assessment with regard to the public speaking task.

The significant variables $(p<.05)$ were included for the multiple linear regression analysis and, as Hosmer and Lemeshow (2000) recommend, so were those with $p \leq .25$ values that were identified in the statistical analyses of the socio-demographic and occupational variables (Table 2) and correlation. The results are shown in Table 3. 
Table 2

Univariate Analysis of the Socio-Demographic and Occupational Variables in Relation to the Self-Statements during Public Speaking (SSPS) $(N=818)$

\begin{tabular}{|c|c|c|c|c|}
\hline \multirow{2}{*}{ Variables } & \multirow{2}{*}{ Categories } & \multirow{2}{*}{$n$} & \multicolumn{2}{|c|}{ SSPS-Total } \\
\hline & & & Average $(S D)$ & Statistical tests \\
\hline \multirow{2}{*}{ Gender } & Male & 346 & $35.83(8.34)$ & $t=2.939$ \\
\hline & Female & 472 & $33.93(10.07)$ & $p=.003^{*}$ \\
\hline \multirow{2}{*}{ Civil status } & Has no partner & 753 & $34.52(9.50)$ & $t=-2.231$ \\
\hline & Has a partner & 65 & $37.23(8.12)$ & $p=.026^{*}$ \\
\hline \multirow{2}{*}{ Living arrangements } & Lives alone & 54 & $33.78(9.48)$ & $t=-0.773$ \\
\hline & Lives with someone & 764 & $34.80(9.42)$ & $p=.440$ \\
\hline \multirow{2}{*}{ Higher education institution } & Private & 340 & $35.23(8.95)$ & $t=1.257$ \\
\hline & Public & 478 & $34.39(9.73)$ & $p=.209$ \\
\hline \multirow{3}{*}{ Areas of knowledge } & Human sciences & 318 & $33.99(9.70)$ & \multirow{3}{*}{$\begin{array}{c}F=2.047 \\
p=.130\end{array}$} \\
\hline & Exact sciences & 302 & $34.91(9.61)$ & \\
\hline & Biological sciences & 198 & $35.68(8.58)$ & \\
\hline \multirow{2}{*}{ Other undergraduate course } & Yes & 51 & $37.02(8.76)$ & \multirow{2}{*}{$\begin{array}{c}t=-1.791 \\
p=.074\end{array}$} \\
\hline & No & 767 & $34.58(9.45)$ & \\
\hline \multirow{2}{*}{ Vocational course } & Yes & 239 & $35.72(8.98)$ & \multirow{2}{*}{$\begin{array}{c}t=-1.931 \\
p=.054\end{array}$} \\
\hline & No & 579 & $34.33(9.57)$ & \\
\hline \multirow{2}{*}{ High school } & Public & 526 & $34.56(9.45)$ & \multirow{2}{*}{$\begin{array}{c}t=-0.706 \\
p=.481\end{array}$} \\
\hline & Private & 292 & $35.05(9.37)$ & \\
\hline \multirow{2}{*}{$\begin{array}{l}\text { Do you work or do you have } \\
\text { other income }\end{array}$} & Yes & 353 & $35.92(8.98)$ & \multirow{2}{*}{$\begin{array}{l}t=-3.152 \\
p=.002 *\end{array}$} \\
\hline & No & 465 & $33.84(9.66)$ & \\
\hline \multirow{2}{*}{$\begin{array}{l}\text { Direct contact with the public } \\
\text { or other people in work }\end{array}$} & Yes & 284 & $36.52(8.83)$ & \multirow{2}{*}{$\begin{array}{l}t=-4.091 \\
p<.001^{*}\end{array}$} \\
\hline & No & 534 & $33.79(9.59)$ & \\
\hline \multirow{2}{*}{ Do you have a disability } & Yes & 19 & $36.89(6.58)$ & \multirow{2}{*}{$\begin{array}{l}t=-1.429 \\
p=.169\end{array}$} \\
\hline & No & 799 & $34.68(9.47)$ & \\
\hline \multirow{2}{*}{$\begin{array}{l}\text { Do you take psychotropic } \\
\text { medication }\end{array}$} & Yes & 42 & $32.19(10.88)$ & \multirow{2}{*}{$\begin{array}{l}t=1.801 \\
p=0.072\end{array}$} \\
\hline & No & 776 & $34.87(9.32)$ & \\
\hline Age & - & - & - & $\begin{array}{l}r=.062 \\
p=.077\end{array}$ \\
\hline
\end{tabular}

Note. SSPS $=$ Self-statements during public speaking scale; $n=$ number of participants; $S D=$ standard deviation; $t=$ Student's $t ; F=$ Fischer's $\mathrm{F}$ test; $r=$ Pearson 's correlation coefficient; * = significant difference or relationship. 
Table 3

Multiple Linear Regression Analysis of the Socio-Demographic, Occupational and Inter-Personal Variables Associated with Self-Statements during Public Speaking $(N=818)$

\begin{tabular}{|c|c|c|c|c|c|c|}
\hline \multirow{2}{*}{ Model } & \multicolumn{2}{|c|}{$\begin{array}{l}\text { Non-standardized } \\
\text { coefficients }\end{array}$} & \multirow{2}{*}{$\begin{array}{l}\text { Standardized } \\
\text { coefficients }\end{array}$} & \multirow{2}{*}{$t$} & \multirow{2}{*}{$p$} & \\
\hline & Beta & $\begin{array}{l}\text { Standard } \\
\text { error }\end{array}$ & & & & \\
\hline Constant & 7.584 & 1.404 & - & 5.402 & $p<.001$ & \multirow{7}{*}{$\begin{array}{l}\mathrm{R}^{2}=0.398 \\
F=91.084 \\
p<.001 \\
D W=1.880\end{array}$} \\
\hline Factor $4 I H S$ & 1.907 & 0.240 & 0.269 & 7.950 & $p<.001$ & \\
\hline Factor $3 I H S$ & 0.924 & 0.154 & 0.193 & 6.016 & $p<.001$ & \\
\hline Factor $2 I H S$ & 0.915 & 0.151 & 0.192 & 6.049 & $p<.001$ & \\
\hline Factor $1 I H S$ & 0.482 & 0.102 & 0.171 & 4.725 & $p<.001$ & \\
\hline Factor $5 I H S$ & 1.931 & 0.365 & 0.146 & 5.285 & $p<.001$ & \\
\hline Vocational course & 1.153 & 0.568 & 0.056 & 2.030 & $p=.043$ & \\
\hline
\end{tabular}

Note. $t=$ Student's $t ; p=$ associated probability; IHS = Social skills inventory; Factor $1=$ Coping with risk; Factor $2=$ Selfconfidence in expressing positive feelings; Factor 3 = Conversation and social resourcefulness; Factor $4=$ Self-exposure to strangers or new situations; Factor $5=$ Self-control of aggressivity in adverse situations; $\mathrm{R}^{2}=$ determination coefficient $F=$ Fischers $\mathrm{F} ; D W=$ Durbin-Watson index.

The results indicated that IHS-Del-Prette Factor 4 was the most important predictor variable when compared to the others. The regression model $(F=91.084 ; p<.001)$ is given by: SSPS-Total $=7.584+1.907 \times$ IHS Factor 4 $+0.915 \times$ IHS Factor $2+0.924 \times$ IHS Factor $3+$ $1.931 \times$ IHS Factor $5+0.482 \times$ IHS Factor $1+$ $1.153 \times$ Vocational course. This regression line showed that self-assessments about speaking in public are more positive the higher the scores relating to the skill classes: self-exposure to strangers (F4); self-confidence in expressing positive feeling (F2); conversation and social resourcefulness (F3); self-control of aggressivity (F5); coping and self-confidence with risk (F1), and whether the individual has a vocational course. The variables cited were presented in decreasing order of importance to the model.

\section{Discussion}

With regard to the comparisons between college students from different areas of knowledge and institutions of higher education, no differences were observed in relation to their total repertoire of skills and their constituent classes. These results differed from those obtained in other studies of the area, which are described below. Bandeira et al. (2005) found that college students enrolled on exact science courses had a better-prepared repertoire of assertive abilities than those from the human sciences area. Bolsoni-Silva and Loureiro (2015) found that students on humanities courses were more socially skilled than those from the exact sciences.

The divergence in the results between this research and the studies cited may be related to differences in the measurement instruments used for assessing the social skills and also in the academic characteristics of the samples investigated, such as, for example, the undergraduate education module in which the college students were enrolled. Unlike the studies presented, which involved only students enrolled in the final year (Bandeira et al., 2005) and in the initial (first two) and intermediary/ final (last three years) years of undergraduate courses (Bolsoni-Silva \& Loureiro, 2015), the sample used in this research was made up of 
students enrolled up until the fifth educational module of undergraduate courses, in other words, modules prior to their first contact with obligatory syllabus internships. Therefore, given the results of this research and its "dialogue" with the literature of the area, it is assumed that the social skills' repertoires of college students from different areas of knowledge may be similar until they have contact with the aforementioned internships, or with specific practices (social skills training, for example) that help them acquire these skills and/or improve them.

The above hypothesis does not exclude the relevance of learning social skills and the influence of academic demands for doing so, such as: presenting seminars (public speaking), complaining to the teacher about a possibly incorrect assessment mark (speaking with authority), and group work (listening, agreeing/ disagreeing, dealing with criticism, negotiating, arguing, asking and replying to questions, etc.; Del Prette \& Del Prette, 2004). On the other hand, the importance of compulsory syllabus internship needs to be emphasized, because their function is to improve the repertoire of competences and the knowledge of the college student by way of practical experience and by identifying those areas (both personal and professional) that are already well-prepared and those that need some improvement (Monteiro, 2010). In this sense, college students can develop their repertoire of social skills on these internships by observing others and being instructed in appropriate behaviors by their teachers and other trained professionals, who will adapt them to fit the requirements of a certain area of professional activity.

Regarding the classification of the social skills' repertoire of the whole sample, even though there was found to be no difference between the groups that were investigated, greater attention needs to be paid to those individuals who had a deficient repertoire of interpersonal skills. IHS assesses the existence of possible deficits in social skills' performance by estimating the frequency with which individuals exhibit certain social skills in an interpersonal situation. According to Elliott and Gresham (1993), this type of deficit can be caused by: (a) a lack of sufficient practice in performing a specific skill, or not receiving feedback related to how it was carried out, with the aim of improving it; (b) a lack of models or opportunities that stimulate appropriate behavior; (c) a lack of reinforcement in the environment with regard to the individual's behavior; and (d) problem-behaviors that are external (discussions with others and arguments), internal (anxiety, depression and low self-esteem) and hyperactive (distraction, impulsiveness and restlessness). Faulty discrimination can also be added; this occurs when individuals are unable to adequately choose when the performance of a particular skill, which already exists in their repertoire, is appropriate.

Since social skills are basic elements for interpersonal relationships (Del Prette \& Del Prette, 2001a) and relationship problems (Castro \& Teixeira, 2013; Pascua-Cantarero, 2016) and social integration difficulties (Pascua-Cantarero, 2016) may aggravate dissatisfaction with the college experience and lead to increased student drop-out, it is believed that the participants in this study who exhibited a good, below-the-median and a deficient repertoire of social skills might possibly be indicated for Social Skills Training (THS) programs, once their specific deficits have been assessed. THS has been documented as an effective alternative for the interpersonal development of college students (Lima \& Soares, 2015; Lopes, Dascanio, Ferreira, Del Prette, \& Del Prette, 2017) and so it could reduce dropout rates in higher education, since a wellprepared repertoire of social skills can facilitate college students' adaptation to higher education (Soares, Francischetto, Peçanha, Miranda, \& Dutra, 2013; Soares et al., 2017).

With regard to the significant correlations obtained in this research, it was found that: (a) the better prepared the overall repertoire of social skills of the college students, and especially of the confrontation with risk, self-confidence in expressing positive feelings, conversation and social resourcefulness, self-exposure to strangers or new situations and self-control of aggressivity in adverse situations classes, the more positively they assessed their own performance when faced 
with situations of having to speak in public; and (b) the more refined the students' social skills repertoire for speaking in public, the more positive were heir self-assessments of this task. Given the above, there is a direct relationship between social skills and self-assessments (cognition) about speaking in public. According to Caballo (2003), self-assessments of one's own social performance are one of the cognitive components of social skills. According to the author, positive self-assessments are found in socially skillful behavior.

The present study allowed the relationships between some of the socio-demographic and occupational variables of college students and their self-assessments about speaking in public to be checked. As for gender, the results corroborate the data found in literature (Marinho et al., 2017; Osório et al., 2012), where men have more positive self-assessments than women. It is assumed, therefore, that these results may be related to sociocultural demands and expectations that are more permissive for men and more restricting for women, making the task of public speaking a greater challenge for females.

It was also found that college students who had a partner, work or their own income and direct contact with the public gave a more positive assessment of their performance in public speaking tasks. It is believed that these factors may allow contact with demands that promote a better development of these self-assessments, which partially explains the results. However, these data were not found in other studies in the area, demonstrating the need for further research for more consistent comparisons.

Concerning the multiple linear regression analysis, the IHS-Del-Prette Factor 4 (selfexposure to strangers and new situations) obtained a higher predictive value for selfassessments in public speaking, followed by Factors 2 (self-confidence in expressing positive feelings), 3 (conversation and social skills), 5 (self-control of aggressivity) and 1 (coping and self-confidence with risk) and with the vocational course variable. These results indicate that a well-prepared repertoire of the skill classes mentioned above and having a vocational course are associated with more positive selfassessments of public speaking tasks. However, no research was found on this subject in literature, reinforcing the need for further research for more consistent comparisons.

This study had some limitations with regard to the methodological procedures it employed. Initially, the groups proved not to be equivalent as to the socio-demographic and occupational variables being assessed. This was due to the type of research design employed, which is called Static Group Comparison. According to Selltiz et al. (1987), in this type of design, the groups are not expected to be equivalent because they are naturally derived and may differ in relation to different socio-demographic and occupational variables, which shows the need for great care when interpreting the results that were found.

In addition to the non-equivalent groups, this research was carried out with only two HEIs from the state of Minas Gerais, making it impossible to make generalizations and extrapolate the results to other institutions and regions in the country. The study was also carried out using a single assessment and, therefore, it was not possible to monitor the college students who were the sample of this study to check whether their repertoire of social skills and their self-assessments with regard to public speaking evolved during their time at college.

\section{Conclusions}

In general terms the present study made it possible to advance knowledge in the area, considering that research was found that characterized and compared the repertoire of social skills of college students enrolled only in humanities and exact science courses in public institutions of higher education. No studies were found that investigate the relationships and associations between social skills and self-assessments of speaking in public. With regard to the classification of the social skills' repertoire, the data found are of concern, because most college students had a good repertoire of social skills that was below the median, or a 
deficient repertoire. Therefore, there needs to be intervention with this population that aims at them acquiring and improving their social skills, which will lead to better quality interpersonal relations, their adaptation to the academic environment and their preparation for the job market. Among the intervention possibilities found in literature, Social Skills Training in groups is indicated as being an effective alternative for the interpersonal development of college students (Lima \& Soares, 2015; Lopes et al., 2017).

In addition to the little research on the subject of this study and a lack of a gold-standard instrument for assessing the social skills of college students, as seen in the studies found in this area, another factor that made it difficult to compare the research related to the academic characteristics of the samples used in this study and in other work developed in this area. In this study the undergraduate module selected to characterize the repertoire of social skills differed from that in other studies in the area, making it impossible to discuss the differences between the areas of knowledge that were investigated in a more consistent manner.

Critical analysis of the results of this research points to the need for new studies with larger samples that include students from all areas of knowledge and types of higher education institution, located in different regions in the country and with a proper matching of their socio-demographic, occupational and academic characteristics, thus guaranteeing the equivalence of the groups and, consequently, greater external validity of the data obtained. It is also worth noting the importance of carrying out longitudinal research that checks the changes in the repertoire of social skills and self-assessments of college students during undergraduate modules and explores the relationship between these skills and college drop-out.

\section{References}

Angélico, A. P. (2009). Transtorno de ansiedade social e habilidades sociais: Estudo psicométrico e empírico (Doctoral dissertation). Universidade de São Paulo, Ribeirão Preto, SP, Brazil.
Angélico, A. P., Crippa, J. A. S., \& Loureiro, S. R. (2012). Transtorno de ansiedade social e habilidades sociais de falar em público: Estudo experimental. Estudos e Pesquisas em Psicologia, 12(1), 10-35. Retrieved from http:// pepsic.bvsalud.org/pdf/epp/v12n1/v12n1a02. pdf

Angélico, A. P., Crippa, J. A. S., \& Loureiro, S. R. (2013). Social anxiety disorder and social skills. In F. L. Osório (Ed.), Social anxiety disorder: From research to practice (pp. 63-80). Nova York: Nova Science.

Bandeira, M., Costa, M. N., Del Prette, Z. A. P., Del Prette, A., \& Gerk-Carneiro, E. (2000). Qualidades psicométricas do Inventário de Habilidades Sociais: Estudo sobre a estabilidade temporal e a validade concomitante. Estudos de Psicologia (Natal), 5(2), 401-419. doi: 10.1590/ S1413-294X2000000200006

Bandeira, M., Quaglia, M. A. C., Bachetti, L. S., Ferreira, T. L., \& Souza, G. G. (2005). Comportamento assertivo e sua relação com ansiedade, locus de controle e auto-estima em estudantes universitários. Estudos de Psicologia (Campinas), 22(2), 111-122. doi: 10.1590/ S0103-166X2005000200001

Bardagi, M.P., \& Hutz, C. S. (2012). Rotina acadêmica e relação com colegas e professores: Impacto na evasão universitária. Psico, 43(2), 174184. Retrieved from http://revistaseletronicas. pucrs.br/ojs/index.php/revistapsico/article/ view/7870/8034

Bolsoni-Silva, A. T., \& Loureiro, S. R. (2015). Social skills of undergraduates without mental disorders: Academic and socio-demographic variables. Psico-USF, 20(3), 447-459. doi: $10.1590 / 1413-82712015200307$

Bussab, W. O., \& Morettin, P. A. (2017). Estatística básica (9nd Ed.). São Paulo, SP: Saraiva

Caballo, V. E. (2003). Elementos componentes da habilidade social. In V. E. Caballo (Ed.), Manual de avaliação e treinamento das habilidades sociais (pp. 17-97). São Paulo, SP: Santos.

Castro, A. K. S. S., \& Teixeira, M. A. P. (2013). A evasão em um curso de psicologia: Uma análise qualitativa. Psicologia em Estudo, 18(2), 199209. doi: 10.1590/S1413-73722013000200002

Carter, E. W., Austin, D., \& Trainor, A. A. (2012). Predictors of postschool employment outcomes for young adults with severe disabilities. Journal 
of Disability Policy Studies, 23(1), 50-63. doi: 10.1177/1044207311414680

Clevenger, T. J., \& Phifer, G. (1959). What do beginning college speech texts say about stage fright? The Speech Teacher, 8(1), 1-10. doi: $10.1080 / 03634525909376987$

Cordasso, J. A., Silva, R. T. P., Pelegrini, P., \& Baggenstoss, S. (2016). Fatores determinantes na evasão de acadêmicos no ensino superior: Estudo em um município do norte matogrossense. In Anais, XVI Coloquio Internacional de Gestión Universtiraria - CIGU. Arequipa, Perú.

Del Prette, A., \& Del Prette Z. A. P. (2001a). Psicologia das relações interpessoais: Vivências para o trabalho em grupo. Petrópolis, RJ: Vozes.

Del Prette, Z. A. P., \& Del Prette, A. (2001b). Inventário de Habilidades Sociais (IHS-DelPrette): Manual de aplicação, apuração $e$ interpretação. São Paulo, SP: Casa do Psicólogo.

Del Prette, Z. A. P., \& Del Prette, A. (2004). Desenvolvimento interpessoal: Uma questão pendente no ensino universitário. In E. Mercuri \& S. Polydoro (Eds.), Estudante universitário: Características e experiências de formação (pp. 105-128). Taubaté, SP: Cabral Editora e Livraria Universitária.

Del Prette, Z. A. P., \& Del Prette, A. (2005). Psicologia das habilidades sociais na infância: Teoria e prática. Petrópolis, RJ: Vozes.

Del Prette, Z. A. P., Del Prette, A., \& Barreto, M.C.M. (1998). Análise de um Inventário de Habilidades Sociais (IHS-Del-Prette) em uma amostra de universitários. Psicologia: Teoria e Pesquisa, 14(3), 219-228

Del Prette, Z. A. P., Del Prette, A., \& Correia, M. F. B. (1992). Competência social: Um estudo comparativo entre alunos de psicologia, serviço social e engenharia mecânica. In Anais, I Congresso Nacional de Psicologia Escolar e Educacional. Campinas, SP.

Elliott, S. N., \& Gresham, F. M. (1993). Social skills interventions for children. Behavior Modification, 17(3), 287-313. doi: $10.1177 / 01454455930173004$

Furtado, E. S., Falcone, E. M. O., \& Clark, C. (2003). Avaliação do estresse e das habilidades sociais na experiência acadêmica de estudantes de medicina de uma universidade do Rio de
Janeiro. Interação em Psicologia, 7(2), 43-51. doi: $10.5380 /$ psi.v7i2.3222

Goberman, A. M., Hughes, S., \& Haydock, T. (2011). Acoustic characteristics of public speaking: Anxiety and practice effects. Speech Communication, 53(6), 867-876. doi: 10.1016/j. specom.2011.02.005

Hofmann, S. G., \& DiBartolo, P. M. (2000). An instrument to assess self-statements during public speaking: Scale development and preliminary psychometric properties. Behavior Therapy, 31(3), 499-515. Retrieved from https://www. ncbi.nlm.nih.gov/pmc/articles/PMC1475776/ pdf/nihms-10370.pdf

Hosmer, D. W., \& Lemeshou, S. (2000). Applied logistic regression. New York: John Wiley and Sons.

Landim, A. K. P., Costa, C. F., Conilheiro, D., Sá, E. S., Nunes, E. C., Santos, E. E., ...Martinez, A. (2000). Ansiedade social em estudantes universitários: Preocupações mais emergentes. Revista Unicastelo, 3(3), 185-192.

Lima, C. A., \& Soares, A. B. (2015). Treinamento em habilidades sociais para universitários no contexto acadêmico: Ganhos e potencialidades em situações consideradas difíceis. In Z. A. P. Del Prette, A. B. Soares, C. S. Pereira-Guizo, M. F. Wagner, \& V. B. R. Leme (Eds.), Habilidades sociais: Diálogos e intercâmbios sobre pesquisa e prática (pp. 22-43). Novo Hamburgo, RS: Sinopsys.

Lobo, M. B. C. M. (2017). A evasão no ensino superior brasileiro - novos dados. Estadão. Retrieved from http://educacao.estadao.com.br/ blogs/roberto-lobo/497-2/

Lopes, D. C., Dascanio, D., Ferreira, B. C., Del Prette, Z. A., \& Del Prette, A. (2017). Treinamento de habilidades sociais: Avaliação de um programa de desenvolvimento interpessoal profissional para universitários de ciências exatas. Interação em Psicologia, 21(1), 55-65. doi: 10.5380/psi. v21i1.36210

Marinho, A. C. F., Medeiros, A. M., Gama, A. C. C., \& Teixeira, L. (2017). Fear of public speaking: Perception of college students and correlates. Journal of Voice, 31(1), 127.e7-127.e11. doi: 10.1016/j.jvoice.2015.12.012

Monteiro, R. M. (2010). Vivências e percepções de estágio em Psicologia: Estudo comparativo entre estagiários da Universidade de Minho e 
da Universidade de Coimbra (Master's thesis, Universidade de Coimbra, Portugal).

Osório, F. L., Crippa, J. A. S., \& Loureiro, R. S. (2008). Escala para Auto-Avaliação ao Falar em Público (SSPS): Adaptação transcultural e consistência interna da versão brasileira. Revista de Psiquiatria Clínica, 35(6), 207-11. doi: 10.1590/S0101-60832008000600001

Osório, F. L., Crippa, J. A. S., \& Loureiro, S. R. (2012). Aspectos cognitivos do falar em público: Validação de uma escala de autoavaliação para universitários brasileiros. Revista de Psiquiatria Clínica, 39(2), 48-53. doi: 10.1590/S010160832012000200002

Pascua-Cantarero, P. M. (2016). Factores relacionados con la deserción en el primer y segundo año de estudio en la carrera de enseñanza de la matemática de la universidad nacional de Costa Rica. Revista Electrônica Educare, 20(1), 1-23. doi: $10.15359 /$ ree.20-1.5

Phillips, B. N., Kaseroff, A. A., Fleming, A. R., \& Huck, G. E. (2014). Work-Related social skills: Definitions and interventions in public vocational rehabilitation. Rehabilitation Psychology, 59(4), 386-398. doi: 10.1037/rep0000011

Saldaña, P. (2016). Mais universitários trancam curso do que concluem graduação. Folha de São Paulo. Retrieved from http://www1. folha.uol.com.br/educacao/2016/03/1747061mais-alunos-trancam-curso-do-que-concluemgraduacao.html
Selltiz, C., Wrightsman, L. S., \& Cook, S. W. (1987). Métodos de pesquisa nas relações sociais: Delineamentos de pesquisa (2nd ed., Vol. 2). São Paulo, SP: EPU.

Soares, A. B., \& Del Prette, Z. A. P. (2015). Habilidades sociais e adaptação à universidade: Convergências e divergências dos construtos. Análise Psicológica, 2(33), 139-151. doi: 10.14417/ap.911

Soares, A. B., Francischetto, V., Peçanha, A. P. C. L., Miranda, J. M., \& Dutra, B. M. S. (2013). Intelligence and social competence in university adaptation. Estudos de Psicologia, 30(3), 317328. doi: 10.1590/S0103-166X2013000300001

Soares, A. B., Santos, Z. A., Andrade, A. C., \& Souza, M. S. (2017). Expectativas acadêmicas e habilidades sociais na adaptação à universidade. Ciências Psicológicas, 11(2), 77-88. doi: 10.22235/cp.v11i2.1349

Weeks, J. W., \& Zoccola, P. M. (2015). "Having the heart to be evaluated": The differential effects of fears of positive and negative evaluation on emotional and cardiovascular responses to social threat. Journal of Anxiety Disorders, 36, 115126. doi: 10.1016/j.janxdis.2015.08.004

Received: $1 \% 07 / 2018$

$1^{\text {st }}$ revision: 03/10/2018

Accepted: 03/10/2018

(cc)BY (C) The Author(s), 2018. Open Access. This article is distributed under the terms of the Creative Commons Attribution 4.0 International License (http://creativecommons.org/licenses/by/4.0/), which permits unrestricted use, distribution, and reproduction in any medium, provided you give appropriate credit to the original author(s) and the source, provide a link to the Creative Commons license, and indicate if changes were made. 